\title{
Tissue Kallikrein Deficiency
}

National Cancer Institute

\section{Source}

National Cancer Institute. Tissue Kallikrein Deficiency. NCI Thesaurus. Code C131651.

A disorder characterized by the partial or complete absence of tissue-type kallikrein activity in the tissues and glandular secretions where it is normally present. 